\title{
FAKTOR YANG BERKONTRIBUSI TERHADAP JUMLAH PENERIMAAN DANA ZAKAT PADA LEMBAGA ZAKAT DI KOTA SURABAYA ${ }^{1)}$
}

\author{
Farid Nugroho \\ Program Studi Ekonomi Islam-Fakultas Ekonomi dan Bisnis-Universitas Airlangga \\ Email: faridnugroho32@gmail.com \\ Tika Widiastuti \\ Departemen Ekonomi Syariah-Fakultas Ekonomi dan Bisnis-Universitas Airlangga \\ Email:widasus@yahoo.com
}

\begin{abstract}
:
The aim of this study is to determine and analyze the contribution of technological factor, accessibility factor, credibility factor, and programs factor of zakat institutions to the zakat funds revenue received by zakat institutions in Surabaya. This study used a qualitative approach with case study strategy. Data collected through interviews with informants and direct observation to the object of the research. The result of this study is there are several factors that have important contribution to zakat revenue at zakat institution in Surabaya. The researcher found accessibility, credibility and zakat collection program during Ramadhan have important contribution to the revenue of zakat funds, while technology has not been widely used by muzakki to make payment of zakat.
\end{abstract}

Keywords : Technology, Accesibility, Credibility, Programs

\section{Pendahuluan}

Zakat merupakan salah satu rukun Islam terpenting setelah sholat, hal ini dibuktikan dengan banyaknya ayat yang ada pada Al-Qur'an yang memuat perintah shalat dan di ikuti oleh perintah untuk berzakat. Sholat merupakan aktivitas habluminallah (hubungan manusia dengan Allah SWT) dan zakat merupakan aktivitas habluminannas (hubungan sesama manusia).

Zakat dibahas dalam pokok bahasan 'ibadah', karena dipandang bagian yang tidak terpisahkan dari sholat. Zakat juga sesungguhnya merupakan bagian sistem sosial ekonomi Islam, oleh karena itu dibahas dalam buku-buku tentang strategi dan hukum ekonomi Islam (Qardhawi, 1999 : 3).
Hukum zakat adalah fardhu ain bagi setiap Muslim yang hartanya telah mencapai nishab, nishab adalah jumlah minimum harta yang wajib dikeluarkan zakatnya. Jika suatu harta telah mencapai nishab, maka harta tersebut wajib dibayarkan zakatnya. Zakat dihitung berdasarkan total seluruh kekayaan yang dimiliki, nishab termasuk dalam perhitungan harta yang wajib dibayarkan zakatnya.

Indonesia merupakan negara dengan penduduk Muslim terbesar di dunia. Menurut Bank Dunia, penduduk Indonesia pada tahun 2012 berjumlah 234 juta jiwa dan $86 \%$ dari penduduk Indonesia beragama Islam, yaitu sekitar 201,2 juta jiwa. Banyaknya jumlah penduduk Muslim

\footnotetext{
1) Jurnal ini merupakan bagian dari skripsi dari Farid Nugroho, NIM: 041211432005, yang diuji pada tanggal 9 Februari 2016
} 
Nugroho, et al/Jurnal Ekonomi Syariah Teori dan Terapan Vol. 3 No. 4 April 2016: 295-310; FAKTOR YANG BERKONTRIBUSI TERHADAP JUMLAH PENERIMAAN DANA ZAKAT PADA LEMBAGA ZAKAT DI KOTA SURABAYA

Indonesia belum dibarengi dengan optimalnya pengumpulan dana zakat.

Berdasarkan perhitungan Badan Amil Zakat Nasional (BAZNAS) dan IPB pada tahun 2011 potensi zakat secara nasional yaitu sekitar 217 Triliun Rupiah, sementara itu yang tercatat di BAZNAS pada akhir tahun 2011 baru dapat terhimpun sebesar Rp 1,8 Triliyun (IMZ, 2012).

Di Indonesia, banyak orang belum memahami kewajiban untuk berzakat dan hikmah yang terkandung dari perintah berzakat. Jikapun memahami aturan berzakat, hanya zakat fitrah lah yang ditunaikan.

Masih banyak ditemukan muzakki yang langsung memberikan zakat nya kepada mustahiq. Muzakki tidak membayarkan zakatnya melalui lembaga pengelola zakat disebabkan oleh berbagai faktor, salah satunya adalah minimnya kepercayaan muzakki kepada lembaga pengelola zakat. Badan Amil Zakat maupun Lembaga Amil Zakat dipandang memiliki tingkat kepercayaan publik yang rendah, hal ini disebabkan oleh akuntabilitas yang lemah dan kapasitas program yang masih diragukan (IMZ, 2012).

Amil zakat mempunyai peranan penting. Para amil zakat mempunyai berbagai macam tugas dan pekerjaan, seperti yang dijelaskan oleh Qardhawi (1999:546):

Amil zakat mempunyai tugas dengan semua yang berhubungan dengan pengaturan soal zakat, soal sensus terhadap orang-orang yang wajib zakat dan macam zakat yang diwajibkan padanya, juga besar harta yang wajib dizakati, kemudian mengetahui para mustahik zakat. Berapa jumlah mereka, berapa kebutuhan mereka serta besar biaya yang dapat mencukupi dan hal-hal lain yang merupakan urusan yang perlu ditangani secara sempurna oleh para ahli dan petugas zakat.

Para peneliti pada umumnya melakukan penelitian terhadap faktorfaktor berzakat dari sisi muzakki dan sedikit yang meneliti faktor yang berkontribusi terhadap jumlah penerimaan dana zakat dari sisi lembaga zakat.

Berdasarkan uraian latar belakang yang telah dijelaskan, maka peneliti merumuskan masalah penelitian sebagai berikut. Bagaimana kontribusi faktor teknologi, faktor aksesibilitas, faktor kredibilitas dan faktor program amil zakat terhadap penerimaan dana zakat amil zakat di Kota Surabaya ?

Adapun tujuan penelitian ini untuk mengetahui dan menganalisa kontribusi faktor teknologi, faktor aksesibilitas, faktor kredibilitas, dan faktor program lembaga amil zakat terhadap penerimaan dana zakat yang diterima oleh lembaga zakat di Kota Surabaya

\section{LANDASAN TEORI}

Ekonomi Islam merupakan penerapan ilmu ekonomi dalam peraturan atau perundang-undangan Islam (Sunatullah). (Zadjuli, 1999:8).

Sumber terpenting sistem Ekonomi Islam adalah Al-Qur'an, Al-Hadits dan suri tauladan perilaku tindak ekonomi zaman Rasulullah dan khalifah (Zadjuli, 1999:8). 
Undang Nomor 23 Tahun 2011 tentang Pengelolaan Zakat mengartikan zakat sebagai harta yang wajib dikelvarkan oleh seorang muslim maupun badan usaha untuk diberikan kepada yang berhak menerimanya sesuai dengan syariat Islam.

Zakat menurut istillah fikih berarti sejumlah harta tertentu yang diwajibkan Allah diserahkan kepada orang-orang yang berhak (Qardhawi, 1999:34).

Zakat merupakan salah satu pilar (rukun) dari lima pilar yang membentuk Islam (Huda, 2015:5).

Zakat dipungut berdasarkan Al-Qur'an dan Sunnah. Secara teknis, zakat adalah kontribusi wajib, semacam pajak yang dipungut dari kaum kaya dan didistribusikan kepada kaum miskin atau dibelanjakan oleh negara untuk mewujudkan kesejahteraan kaum miskin dan mereka yang tak berpengharapan (Chaudhry, 2012:254).

Al-Qur'an tidak memberikan penjelasan secara rinci mengenai kekayaan yang wajib dikenakan zakat dan syarat-syarat yang wajib dipenuhi serta tidak menjelaskan besar zakat atas kekayaan tersebut. Persoalan itu diserahkan kepada sunnah Rasulullah SAW, baik dalam bentuk ucapan maupun perbuatan (Qardhawi, 1999 : 122).

Zakat secara umum dibedakan menjadi dua, seperti yang dijelaskan Chaudhry (2012 : 255):

Zakat nafs (jiwa) atau disebut juga dengan zakat fitrah dan zakat harta (maal). Zakat maal meliputi pertama, emas, perak dan logam mulia lainnya, kedua, uang dan surat berharga lainnya, ketiga, perniagaan atau perdagangan, keempat, pertanian, perkebunan dan kehutanan, kelima, peternakan dan perikanan, keeenam, pertambangan, ketujuh, pendapatan dan jasa, kedelapan, rikaz.

Rasulullah SAW tidak hanya menetapkan sebuah sistem model bagi pengumpulan dan pembayaran zakat saja melainkan juga membuat aturan dan regulasi tentangnya seperti yang dijelaskan Chaudhry (2012 : 255):

Zakat bukanlah urusan pribadi melainkan lembaga negara. Praktik Nabi juga menetapkan bahwa sistem zakat diatur di dalam negara Islam sebagai lembaga pemerintah. Sesudah wafatnya Nabi, ketika sebagian orang membangkang untuk membayar zakat, Khalifah Abu Bakar, penerus Rasulullah SAW menyatakan perang terhadap mereka dan memaksa mereka membayar zakat sebagai pungutan negara.

Amil zakat secara tekstual terdapat dalam Q.S At-Taubah ayat 60, memiliki peran yang sangat penting baik dalam pengumpulan dan pendistribusian zakat. (Huda, 2015:171).

Saat ini dapat dipahami bahwa amil zakat bukan orang-perseorangan melainkan badan atau lembaga. Undang-undang No. 23 tahun 2011 tentang pengelolaan zakat menetapkan bahwa BAZNAS (Badan Amil Zakat Nasional) merupakan lembaga yang berwenang melakukan tugas pengelolaan zakat secara nasional. Pada sisi yang lain masyarakat dapat membentuk Lembaga Amil Zakat (LAZ). 
Pada bagian keempat Lembaga Amil

Zakat pasal 17 disebutkan bahwa:

\begin{abstract}
Untuk membantu BAZNAS dalam pelaksanaan pengumpulan, pendistribusian, dan pendayagunaan zakat, masyarakat dapat membentuk LAZ, oleh karena itu lembaga zakat secara umum dapat dibedakan menjadi dua yaitu BAZ (Badan Amil Zakat) dan Non-Baz atau disebut dengan LAZ (Lembaga Amil Zakat).
\end{abstract}

Muzakki adalah salah satu dari kategori masyarakat yang mampu yaitu pendapatan mereka mampu untuk memenuhi kebutuhan pokoknya dan sisanya mencapai satu nishab (Widiastuti, 2014:60).

Mustahiq tergolong pada delapan golongan (ashnaf) seperti yang dijelaskan oleh Widiastuti (2014:61):

Para mustahiq tergolong pada delapan golongan (ashnaf) sebagaimana ditetapkan dalam QS AtTaubah ayat 60, yaitu fakir (fuqara), miskin (masakin), amil (amilin alaiha), muallaf (muallafat ul qulub). membebaskan budak (riqab), orang yang berhutang (gharim), berjuang di jalan Allah SWT (fi sabilillah) dan ibnu sabil (orang yang sedang dalam perjalanan).

Menurut Kamus Besar Bahasa Indonesia. Teknologi adalah keseluruhan sarana untuk menyediakan barangbarang yang diperlukan bagi kelangsungan dan kenyamanan hidup manusia. Dalam kaitannya dengan sistem pengumpulan zakat, teknologi adalah sarana yang memudahkan muzakki untuk menunaikan zakatnya melalui amil zakat.

Program adalah sebuah rencana tindakan yang bertujuan untuk mencapai tujuan yang jelas, dengan rincian tentang apa pekerjaan yang harus dilakukan, oleh siapa, kapan, dan sumber daya apa yang akan digunakan (businessdictionary.com).

Program penghimpunan lembaga zakat adalah serangkaian rancangan kegiatan yang akan dilakukan oleh lembaga Zakat dalam kaitannya untuk menjalankan tugas dan fungsi sebagai lembaga zakat yang menghimpun dana zakat.

Proposisi penelitian ini adalah faktor teknologi, faktor aksesibilitas, faktor kredibilitas dan faktor program lembaga zakat di Kota Surabaya memiliki kontribusi terhadap jumlah penerimaan dana zakat.

\section{METODOLOGI PENELITIAN}

Penelitian ini menggunakan pendekatan kualitatif. Penelitian kualitatif ditujukan untuk mendeskripsikan dan menganalisis fenomena, peristiwa, aktivitas sosial, sikap, kepercayaan, persepsi, dan pemikiran manusia secara individu maupun kelompok. Penelitian kualitatif bersifat induktif. Peneliti membiarkan permasalahan muncul dari data atau dibiarkan terbuka untuk intepretasi (Ghony, 2012 : 14).

\section{Ruang Lingkup Penelitian}

Rumusan masalah merupakan acuan yang digunakan dalam menentukan ruang lingkup penelitian. Dalam penelitian ini, rumusan masalah yang diangkat adalah bagaimana kontribusi faktor teknologi, faktor aksesibilitas, faktor kredibilitas, dan faktor program terhadap penerimaan dana zakat pada sembilan 
Nugroho, et al/Jurnal Ekonomi Syariah Teori dan Terapan Vol. 3 No. 4 April 2016: 295-310; FAKTOR YANG BERKONTRIBUSI TERHADAP JUMLAH PENERIMAAN DANA ZAKAT PADA LEMBAGA ZAKAT DI KOTA SURABAYA

lembaga zakat di Kota Surabaya. Ruang lingkup penelitian ini terbatas pada faktor yang berkontribusi terhadap penerimaan dana zakat pada lembaga zakat di Kota Surabaya.

Lembaga zakat yang diteliti berjumlah sembilan yaitu, BAZNAS Jawa Timur, Rumah Zakat Surabaya, Pos Keadilan Peduli Umat (PKPU) Surabaya, Yayasan Dana Sosial Al Falah (YDSF), Baitul Maal Hidayatullah (BMH), Yayasan Nurul Hayat, Yayasan Yatim Mandiri, Al-Azhar Peduli Ummat Jawa Timur, dan LAZ Masjid AlAkbar Surabaya.

\section{Jenis dan Sumber Data}

Data yang digunakan dalam penelitian ini adalah hasil penggabungan antara data primer dan data sekunder.

Data primer yang digunakan dalam skripsi ini adalah data hasil wawancara dan observasi lapangan lembaga Zaka† dan data sekunder yang digunakan adalah data jumlah penerimaan dana zakat masing - masing lembaga zakat.

\section{Teknik Pengumpulan Data}

Pengumpulan data primer dalam penelitian ini dilakukan dengan cara wawancara kepada informan dan juga observasi secara langsung pada lembaga amil zakat. Pengumpulan data sekunder dilakukan dengan cara dokumentasi terhadap laporan keuangan lembaga zakat di Kota Surabaya.

\section{Teknik Analisis}

Dalam penelitian ini, proses analisis data dilakukan sejak saat pemikiran awal, selama melakukan penelittian, dan pada waktu melakukan intepretasi. Teknik analisis yang digunakan dalam penelitian ini adalah kualitatif deskriptif dengan tujuan untuk mengetahui dan menggambarkan secara jelas dan mendalam mengenai faktor yang berkontribusi terhadap penerimaan dana zakat pada lembaga zakat di Kota Surabaya.

Tahap pertama dimulai sejak awal pengumpulan data, meliputi analisis data baik yang diperoleh melalui observasi, dokumen maupun wawancara yang mendalam dengan pengurus lembaga zakat di Kota Surabaya. Tahap selanjutnya adalah memeriksa kembali kebenaran data, kemudian mengadakan analisis data secara lebih khusus.

\section{Hasil dan Pembahasan}

Objek penelitian yang digunakan dalam penelitian ini adalah sembilan lembaga zakat yang ada di Surabaya yakni BAZNAS Jawa Timur, Baitul Maal Hidayatullah (BMH), Yayasan Dana Sosial Al-Falah (YDSF), Yayasan Nurul Hayat, Rumah Zakat cabang Surabaya, Al-Azhar Peduli Ummat cabang Jawa Timur, Yayasan Yatim Mandiri, Pos Keadilan Peduli Ummat (PKPU) Surabaya, dan LAZ Masjid Al-Akbar Surabaya.

BAZNAS Jawa Timur dibentuk dengan Keputusan Gubernur Jawa Timur, memiliki wewenang untuk melaksanakan tugas pengumpulan, pendistribusian, dan pengelolaan zakat di seluruh Jawa Timur. Melaksanakan fungsi perencanaan, pelaksanaan, pengendalian, pelaporan, 
Nugroho, et al/Jurnal Ekonomi Syariah Teori dan Terapan Vol. 3 No. 4 April 2016: 295-310; FAKTOR YANG BERKONTRIBUSI TERHADAP JUMLAH PENERIMAAN DANA ZAKAT PADA LEMBAGA ZAKAT DI KOTA SURABAYA

dan pertanggungjawaban atas pengumpulan, pendistribusian dan pendayagunaan zakat.

BAZNAS Jawa Timur menerima dana zakat melalui empat cara, Pertama, menerima dana zakat dengan menerima transfer dana zakat melalui rekening Bank Syariah Mandiri, Bank Jatim dan BNI Syari'ah. Kedua, menerima dana zakat di Kantor BAZNAS Jawa Timur di Gedung Islamic Center lantai dua Jalan Raya Dukuh Kupang 122-124 Surabaya. Ketiga, mengerahkan Juru Pungut untuk memberikan layanan jemput zakat ke rumah atau kantor muzakki. Keempat, menerima dana zakat dari payroll system gaji Pegawai Instansi pemerintahan di Provinsi Jawa Timur.

Baitul Maal Hidayatullah (BMH) merupakan lembaga amil zakat yang bergerak dalam penghimpunan dana zakat, infaq, sedekah, kemanusiaan, dan Corporate Social Responsibility perusahaan.

BMH Jawa Timur secara garis besar melakukan penghimpunan dana zakat melalui tiga cara. Cara pertama adalah menerima dana zakat menggunakan rekening dana zakat. BMH Jawa Timur menyediakan rekening bank BCA, BNI, Mandiri, dan Bank Syariah Mandiri untuk menerima dana zakat dari muzakki yang membayarkan zakat melalui cara transfer.

Cara kedua adalah menerima dana zakat di kantor layanan BMH Jawa Timur, muzakki dapat langsung membayar zakat di kantor BMH Jawa Timur di Jalan Raya
Mulyosari. Cara ketiga adalah menerima dana zakat dengan memberikan layanan jemput zakat. Muzakki yang berkeinginan untuk membayar zakat dapat menghubungi BMH Jawa Timur via telepon untuk dilakukan penjemputan dana zakat, BMH Jawa Timur tidak menetapkan angka minimal untuk pengambilan dana zakat dari muzakki.

Yayasan Dana Sosial al Falah (YDSF) didirikan pada 1 Maret 1987, saat ini telah beroperasi di lebih dari 25 propinsi di Indonesia.

YDSF melakukan penghimpunan dana zakat melalui empat cara. Cara pertama adalah menerima dana zakat menggunakan rekening dana zakat. YDSF menyediakan rekening bank BCA, Mandiri, CIMB Niaga, Muamalat dan CIMB Niaga Syariah untuk menerima dana zakat dari muzakki yang membayarkan zakat melalui cara transfer.

Cara kedua adalah menerima dana zakat untuk wilayah Surabaya di Graha Zakat YDSF, muzakki dapat langsung membayar zakat di Graha YDSF di Jalan Kertajaya 8C. Cara ketiga adalah menerima dana zakat dengan memberikan layanan jemput zakat. Muzakki yang berkeinginan untuk membayar zakat dapat menghubungi YDSF via telepon untuk dilakukan penjemputan dana zakat. Dan yang terakhir, adalah menerima zakat dengan payroll system.

Yayasan Nurul Hayat berdiri pada tahun 2001, bergerak dalam bidang 
Nugroho, et al/Jurnal Ekonomi Syariah Teori dan Terapan Vol. 3 No. 4 April 2016: 295-310; FAKTOR YANG BERKONTRIBUSI TERHADAP JUMLAH PENERIMAAN DANA ZAKAT PADA LEMBAGA ZAKAT DI KOTA SURABAYA

layanan sosial dan dakwah. Nurul Hayat sejak awal didirikan sudah dicita-citakan untuk menjadi lembaga milik ummat yang mandiri.

Nurul Hayat melakukan penghimpunan dana zakat melalui empat cara. Cara pertama adalah menerima dana zakat menggunakan rekening dana zakat. Nurul Hayat menyediakan rekening bank BCA, Bank Mandiri, Bank Syari'ah Mandiri, BNI Syariah, Bank CIMB Niaga Syariah, Bank Muamalat, Bank Mega, dan BRI Syari'ah untuk menerima dana zakat dari muzakki yang membayarkan zakat melalui cara transfer.

Cara kedua adalah menerima dana zakat untuk wilayah Surabaya di Kantor Nurul Hayat Surabaya, muzakki dapat langsung membayar zakat di Kantor Nurul Hayat Surabaya di Perum IKIP Gunung Anyar Surabaya. Cara ketiga adalah menerima dana zakat dengan memberikan layanan jemput zakat. Muzakki yang berkeinginan untuk membayar zakat dapat menghubungi Nurul Hayat via telepon atau melalui Whatsapp untuk dilakukan penjemputan dana zakat oleh petugas Nurul Hayat. Dan yang terakhir, adalah menerima zakat dengan payroll system bekerja sama dengan bagian keuangan yang perusahaannya mempercayakan payroll zakat nya ke Nurul Hayat.

Rumah Zakat merupakan sebuah lembaga swadaya masyarakat yang memfokuskan kegiatannya pada pengelolaan zakat, infaq, shodaqoh dan wakaf secara lebih profesional dengan menekankan pembinaan dan pemberdayaan sosial.

Rumah Zakat memiliki cara penghimpunan zakat yang paling update terhadap perkembangan teknologi dibandingkan dengan lembaga zakat yang lain pada penelitian ini. Rumah Zakat menerima pembayaran dana zakat dari muzakki melalui Host to Host Bank Mandiri, Host to Host ATM Bersama, transfer, layanan jemput zakat, dan menerima pembayaran zakat di kantor layanan rumah zakat.

Rumah Zakat menggunakan rekening dari banyak bank untuk menerima dana zakat, diantaranya adalah, Bank Mandiri, Bank Muamalat, Bank BCA, Bank BNI Syariah, Bank Permata Syariah, Bank Mandiri Syari'ah, Bank BNI, Bank Danamon Syariah, Bank Mega Syariah, Bank BTN Syariah, Bank CIMB Niaga Syariah, Bank DKI Syari'ah, Bank BJB Syari'ah, Bank Syari'ah Bukopin, Bank Bank Bll Syari'ah, Bank BRI Syari'ah, Bank OCBC NISP Syari'ah, dan Bank BRI.

Muzakki dapat langsung membayar zakat di kantor Rumah Zakat cabang Surabaya di Jalan Panjang Jiwo Permai. Layanan jemput zakat juga bisa digunakan muzakki dengan menghubungi kantor Rumah Zakat cabang Surabaya melalui telepon untuk dilakukan penjemputan zakat.

Al-Azhar Peduli Ummat adalah lembaga nirlaba yang dibentuk Yayasan Pesantren Islam Al-Azhar yang bertujuan 
Nugroho, et al/Jurnal Ekonomi Syariah Teori dan Terapan Vol. 3 No. 4 April 2016: 295-310; FAKTOR YANG BERKONTRIBUSI TERHADAP JUMLAH PENERIMAAN DANA ZAKAT PADA LEMBAGA ZAKAT DI KOTA SURABAYA

untuk memberdayakan masyarakat dhuafa.

Al-Azhar Peduli Ummat menggunakan rekening dari banyak bank untuk menerima dana zakat, diantaranya adalah, BTN Syariah, Bank Syariah Mandiri, Bank Danamon Syari'ah, Bank BCA, Bank BNI Syariah, Bank Muamalat, Bank BRI Syariah, Bank Mega Syariah, Bank Mandiri, Bank CIMB Niaga Syariah, dan Bank Permata Syari'ah.

Layanan Zakat Home Service diberikan kepada muzakki yang ingin membayarkan zakat dengan layanan jemput zakat, disertai juga dengan layanan konsultasi dan penghitungan zakat. Bagi muzakki yang berdomisili di wilayah Surabaya dan sekitarnya, bisa membayarkan zakat dengan datang langsung ke kantor Al-Azhar Peduli Ummat cabang Jawa Timur di Jalan Raya Mulyosari. Payroll system Al-Azhar Peduli Ummat saat ini lebih difokuskan untuk penerimaan zakat karyawan Yayasan Pesantren Islam Al-Azhar (YPIA) saja.

Yatim Mandiri menggunakan rekening Bank BCA, Bank Mandiri, Bank Syariah Mandiri, Bank Permata Syariah, Bank Muamalat, Bank BRI, dan Bank BNI Syariah untuk menerima transfer dana zakat dari muzakki. Yatim Mandiri juga memberikan kemudahan bagi muzakki dengan memberikan layanan jemput zakat. ZIS Consultant dikerahkan untuk menjemput dana zakat di Kantor dan Rumah muzakki. Muzakki juga bisa langsung membayarkan zakat di kantor cabang Yatim Mandiri.
Kantor cabang Yatim Mandiri untuk wilayah Surabaya berlokasi di Jalan Bendul Merisi Selatan.

PKPU menggunakan rekening bank BCA, bank Mandiri, bank Syari'ah Mandiri, bank BNI, bank BNI Syari'ah, bank BRI, bank BRI Syari'ah, bank Muamalat, bank MNC, bank CIMB Niaga Syariah, bank Danamon Syariah, bank Mega Syariah, bank Permata dan bank Permata syariah untuk menerima transfer dana zakat dari muzakki.

Muzakki yang bertempat tinggal di wilayah Surabaya dan sekitarnya dapat membayar langsung zakatnya ke kantor PKPU cabang Surabaya di Jalan Ngagel Jaya Utara. Layanan jemput zakat juga disediakan oleh PKPU untuk menerima dana zakat dari muzakki, muzakki dapat mengisi form di website pkpu (www.pkpu.org) atau menghubungi kantor cabang PKPU untuk menggunakan layanan jemput zakat.

Penghimpunan dana zakat di LAZ Masjid Al-Akbar hanya melalui tiga cara penghimpunan. Pertama, muzakki langsung datang ke Masjid Al-Akbar Surabaya untuk membayarkan zakat. Kedua, muzakki mentransfer dana zakat menggunakan rekening bank Jatim, bank Jatim Syari' ah, bank Syari'ah Mandiri, dan bank BRI Syari'ah. Ketiga, layanan jemput zakat, muzakki menghubungi sekretariat Masjid Al-Akbar Surabaya untuk dilakukan penjemputan zakat.

BAZNAS Jawa Timur, Yayasan Dana Sosial Al-Falah, Nurul Hayat, dan Rumah 
Nugroho, et al/Jurnal Ekonomi Syariah Teori dan Terapan Vol. 3 No. 4 April 2016: 295-310; FAKTOR YANG BERKONTRIBUSI TERHADAP JUMLAH PENERIMAAN DANA ZAKAT PADA LEMBAGA ZAKAT DI KOTA SURABAYA

Zakat cabang Surabaya menerima sebagian pembayaran zakat dari perusahaan yang mempercayakan pembayaran dana zakat melalui payroll system. Al-Azhar Peduli Ummat cabang Jawa Timur menerima zakat melalui payroll system hanya untuk internal karyawan Yayasan Pesantren Islam AlAzhar. PKPU cabang Surabaya mengarahkan perusahaan yang ingin menggunakan payroll system untuk menguhubungi kantor pusat PKPU. BMH Jawa Timur, Yatim Mandiri dan LAZ Masjid Al-Akbar Surabaya saat ini tidak menggunakan payroll system untuk melakukan penghimpunan dana zakat.

Alur pelaksanaan pembayaran zakat melalui payroll system adalah sebagai berikut, langkah pertama yang dilakukan lembaga zakat adalah edukasi dan sosialisasi mengenai zakat kepada bagian keuangan dan pimpinan perusahaan. Jika pimpinan perusahaan, bagian keuangan, dan karyawan yang dipotong gajinya menyetujui untuk terjadi pembayaran zakat menggunakan payroll system, maka langkah kedua adalah bagian kevangan perusahaan memotong gaji karyawan senilai zakat yang harus dibayarkan. Langkah ketiga, bagian keuangan mengirimkan zakat yang telah dikumpulkan dari gaji karyawan kepada lembaga zakat.

Semua Lembaga Zakat yang diteliti menyediakan rekening untuk menerima dana zakat. Jumlah rekening masingmasing lembaga zakat bervariasi. Rumah
Zakat adalah lembaga zakat yang memiliki jumlah rekening terbanyak dengan delapanbelas rekening. Banyaknya jumlah rekening dana zakat yang disediakan Rumah Zakat bertujuan untuk menyediakan alternatif rekening dana zakat pada bank yang digunakan oleh muzakki. Selanjutnya, banyaknya rekening yang disediakan juga untuk mencapai target Rumah Zakat yang ingin menerapkan pembayaran zakat $80 \%$ cashless atau tidak melalui pembayaran tunai.

Lembaga zakat dalam penelitian ini yang proporsi penerimaan dana zakatnya paling besar didapatkan dari transfer muzakki adalah PKPU, sekitar 60-70\% penerimaan dana zakat PKPU berasal dari muzakki yang membayarkan dana zakatnya melalui transfer ke rekening dana zakat PKPU. Pada lembaga zakat yang lain ditemukan bahwa proporsi penerimaan dana zakat dari transfer lebih kecil dibandingkan dengan metode pembayaran zakat yang lain.

Alur pembayaran zakat melalui transfer adalah sebagai berikut, langkah pertama yang dilakukan lembaga zakat adalah melakukan sosialisasi, edukasi, dan persuasi berzakat kepada muzakki. Langkah kedua adalah menunjukkan kredibilitas, program, dan cara transfer zakat kepada Muzakki. Berikutnya, Muzakki yang percaya terhadap lembaga zakat, sudah paham mengenai ketentuan berzakat serta paham cara melakukan 
Nugroho, et al/Jurnal Ekonomi Syariah Teori dan Terapan Vol. 3 No. 4 April 2016: 295-310; FAKTOR YANG BERKONTRIBUSI TERHADAP JUMLAH PENERIMAAN DANA ZAKAT PADA LEMBAGA ZAKAT DI KOTA SURABAYA

transfer akan melakukan transfer dana zakat kepada lembaga zakat.

Al-Azhar Peduli Ummat (APU) cabang Jawa Timur dan LAZ Masjid Al-Akbar Surabaya adalah lembaga zakat dengan prosentase penerimaan dana zakat dari muzakki yang datang ke kantor layanan paling besar dibandingkan dengan lembaga zakat lainnya. BAZNAS Jawa Timur, YDSF, Nurul Hayat, Rumah Zakat cabang Surabaya, Yatim Mandiri, dan PKPU cabang Surabaya proporsi penerimaan dana zakat dari muzakki yang datang langsung ke kantor cukup kecil dari jumlah keseluruhan penerimaan dana zakat yang diterima.

Alur pembayaran zakat oleh muzakki yang langsung membayarkan zakatnya di Kantor Lembaga Zakat adalah sebagai berikut, langkah pertama yang dilakukan lembaga zakat adalah melakukan sosialisasi, edukasi, dan persuasi berzakat kepada muzakki. Langkah kedua adalah menunjukkan Kredibilitas, Program, dan Alamat kantor lembaga zakat kepada Muzakki. Berikutnya, Muzakki yang ingin membayarkan zakat, namun masih perlu untuk mengkonsultasikan jumlah pembayaran zakat kepada lembaga zakat bisa mendatangi kantor zakat dan membayarkan dana zakat.

BAZNAS Jawa Timur, BMH Jawa Timur, Yayasan Dana Sosial Al-Falah, Nurul Hayat, Rumah Zakat cabang Surabaya dan Yatim Mandiri adalah lembaga zakat yang proporsi terbesar penerimaan dana zakatnya berasal dari layanan jemput zakat. Lembaga zakat yang kontribusi penerimaan dana zakatnya berasal dari layanan jemput zakat menekankan pendekatan silaturahmi kepada muzakki.

Al-Azhar Peduli Ummat (APU) Jawa Timur, Pos Keadilan Peduli Umat (PKPU) cabang Surabaya dan Lembaga Amil Zakat Masjid Al-Akbar Surabaya juga memberikan layanan jemput zakat, tetapi proporsi penerimaan dana zakat dari layanan jemput zakat lebih kecil dibandingkan dengan cara penghimpunan dana zakat yang lain. Penerimaan terbesar dana zakat Al-Azhar Peduli Ummat (APU) Jawa Timur dan Lembaga Amil Zakat Masjid Al-Akbar Surabaya berasal dari muzakki yang datang langsung ke kantor layanan, sedangkan Penerimaan dana zakat Pos Keadilan Peduli Umat (PKPU) cabang Surabaya yang terbesar berasal dari transfer muzakki.

Alur pembayaran zakat oleh muzakki yang membayarkan zakatnya menggunakan layanan jemput zakat adalah sebagai berikut, langkah pertama yang dilakukan lembaga zakat adalah melakukan sosialisasi, edukasi, dan persuasi berzakat kepada muzakki. Langkah kedua adalah menunjukkan Kredibilitas, Program, dan nomor telepon lembaga zakat kepada Muzakki. Berikutnya, Muzakki yang ingin membayarkan zakat, namun masih perlu untuk mengkonsultasikan jumlah pembayaran zakat kepada lembaga zakat bisa menghubungi lembaga zakat 
Nugroho, et al/Jurnal Ekonomi Syariah Teori dan Terapan Vol. 3 No. 4 April 2016: 295-310; FAKTOR YANG BERKONTRIBUSI TERHADAP JUMLAH PENERIMAAN DANA ZAKAT PADA LEMBAGA ZAKAT DI KOTA SURABAYA

untuk menggunakan layanan jemput zakat dan membayarkan zakat kepada petugas jemput zakat.

BAZNAS Jawa Timur sampai saat ini belum melakukan audit eksternal terhadap laporan keuangannya. Mahalnya biaya audit eksternal menjadi kendala BAZNAS Jawa Timur untuk melakukan audit eksternal, BAZNAS Jawa Timur lebih memilih untuk mengalokasikan dana yang dimiliki untuk penyaluran kepada mustahiq.

Yayasan Dana Sosial Al-Falah (YDSF) dan Yayasan Nurul Hayat adalah lembaga zakat yang paling rutin menunjukkan hasil audit eksternal menggunakan media spanduk di jalan raya untuk wilayah Surabaya. YDSF dan Nurul Hayat mendapatkan predikat "wajar tanpa pengecualian" untuk hasil audit eksternal dari Kantor Akuntan Publik yang melakukan audit.

Baitul Maal Hidayatullah (BMH) cabang Jawa Timur, Rumah Zakat cabang Surabaya, Al-Azhar Peduli Ummat cabang Jawa Timur, Pos Keadilan Peduli Ummat (PKPU) cabang Surabaya menyerahkan laporan keuangan kepada kantor pusat masing-masing untuk dilakukan audit eksternal oleh Kantor Akuntan Publik.

LAZ Masjid Al-Akbar Surabaya (LAZ MAS) tidak melakukan audit eksternal secara khusus terhadap laporan keuangannya. Audit eksternal dilakukan bersama dengan laporan keuangan Masjid Al-Akbar Surabaya, karena segala aktivitas keuangan melalui satu pintu yaitu bagian kevangan manajemen Masjid AlAkbar Surabaya.

Pada bulan Ramadhan, semua lembaga zakat mengalami kenaikan penerimaan jumlah dana zakat yang cukup signifikan jika dibandingkan dengan pada selain bulan Ramadhan. $\mathrm{Hal}$ ini sejalan dengan penelitian Hamidiyah (2004) yang menyatakan bahwa momen bulan Ramadhan berpengaruh positif terhadap pengumpulan dana zakat.

Banyak muzakki yang berasumsi bahwa berzakat di bulan Ramadhan lebih afdhal dan mendapatkan pahala yang berlipat ganda, sehingga muzakki ramai untuk membayarkan zakatnya pada bulan Ramadhan. Peningkatan penerimaan dana zakat selain disebabkan oleh peningkatan muzakki yang membayarkan zakat di bulan Ramadhan, juga disebabkan oleh adanya tambahan aktivitas penghimpunan yang dilakukan oleh masing-masing lembaga zakat. Beberapa lembaga zakat membuka gerai penghimpunan zakat di pusat keramaian seperti pusat perbelanjaan, pusat perkantoran, dan rumah sakit.

Kenaikan penerimaan dana zakat pada bulan Ramadhan pada lembaga zakat yang diteliti dalam penelitian ini bervariasi. Kenaikan paling sedikit adalah penerimaan dana zakat di bulan Ramadhan dua kali lipat jika dibandingkan dengan pada selain bulan Ramadhan dan yang paling tinggi adalah sepuluh kali lipat jika dibandingkan selain 
bulan Ramadhan, dan juga ditemukan di LAZ Masjid Al-Akbar Surabaya dimana kebanyakan muzakki membayarkan zakat di bulan Ramadhan saja.

Yatim Mandiri adalah satu satunya lembaga zakat dalam penelitian ini yang aktif dan rutin dalam kegiatan sponsorship, dalam perencanaan Yatim Mandiri terdapat anggaran khusus untuk kegiatan sponsorship. Yatim Mandiri memandang kegiatan sponsorship sebagai media komunikasi dan promosi yang efektif, di setiap kegiatan sponsorship Yatim Mandiri juga melakukan penghimpunan dana zakat, infaq, shadaqah, dan juga donasi lainnya.

Lembaga zakat dalam penelitian ini, selain Yatim Mandiri, menyatakan sangat selektif dan cukup menghindari kegiatan sponsorship karena biayanya yang cukup besar. Lembaga Zakat lebih memilih menggunakan dana yang ada untuk memaksimalkan kegiatan penyaluran manfaat kepada mustahiq.

Tidak semua lembaga zakat yang diteliti dalam penelitian ini dapat mengikuti program zakat memotong penghasilan bruto. Hanya Lembaga Zakat yang teregistrasi dan diakui oleh Badan Amil Zakat Nasional (BAZNAS), Kementrian Agama dan Ditjen Pajak yang dapat mengikuti program zakat mengurangi penghasilan bruto.

Lembaga zakat dalam penelitian ini yang bisa mengikuti program zakat memotong penghasilan bruto adalah BAZNAS Jawa Timur dan Lembaga Amil
Zakat yang telah berstatus Lembaga Amil Zakat Nasional (LAZNAS), diantaranya adalah Baitul Maal Hidayatullah (BMH), Yayasan Dana Sosial Al-Falah (YDSF), Yayasan Nurul Hayat, Rumah Zakat dan Pos Keadilan Peduli Umat (PKPU). Yayasan Yatim Mandiri meskipun saat ini telah mendapat rekomendasi dari Badan Amil Zakat Nasional (BAZNAS) pusat, masih dalam proses untuk mendapatkan status LAZNAS.

Muzakki di Surabaya masih jarang yang memanfaatkan regulasi pemotongan zakat terhadap penghasilan bruto, sangat jarang sekali muzakki menanyakan program ini kepada Lembaga Zakat.

Faktor Teknologi yang dimaksudkan dalam penelitian ini adalah sarana yang memudahkan muzakki untuk menunaikan zakatnya melalui lembaga zakat. Sesuai dengan hadits nabi yang diriwayatkan oleh Imam Muslim.

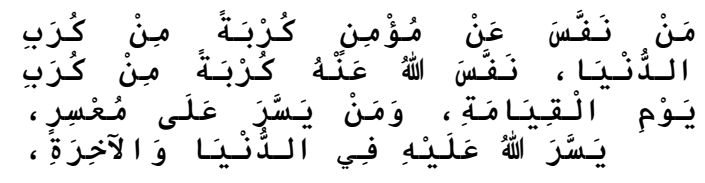

Artinya :"Barangsiapa melepaskan kesusahan seorang mukmin di dunia niscaya Allah akan melepaskan kesusahannya di akhirat. Siapa yang memudahkan orang yang kesusahan, niscaya Allah akan memudahkan (urusannya) di dunia dan di akhirat" (H.R Muslim).

Transfer dan payroll system merupakan kemudahan yang disediakan lembaga zakat untuk muzakki membayar zakat. Sesuai yang diuraikan oleh Hafidhuddin (2003:96), lembaga zakat yang memberikan kemudahan muzakki untuk 
Nugroho, et al/Jurnal Ekonomi Syariah Teori dan Terapan Vol. 3 No. 4 April 2016: 295-310; FAKTOR YANG BERKONTRIBUSI TERHADAP JUMLAH PENERIMAAN DANA ZAKAT PADA LEMBAGA ZAKAT DI KOTA SURABAYA

membayarkan kewajiban zakat, niscaya akan dimudahkan urusannya oleh Allah SWT.

Faktor Aksesibilitas lembaga zakat dapat didefinisikan sebagai ukuran kemudahan yang di dapatkan muzakki untuk menunaikan zakat melalui lembaga zakat. Faktor aksesibilitas yang disediakan oleh lembaga zakat sesuai dengan firman Allah dalam Al-Qur'an pada surat At Taubah ayat 103.

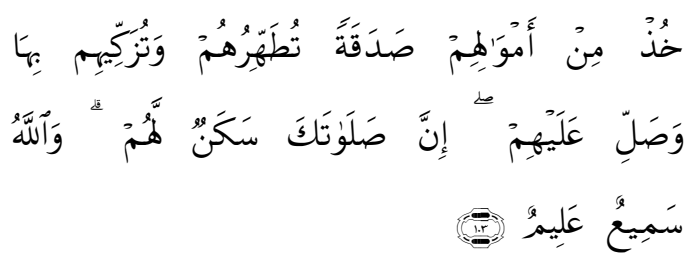

Artinya :"Ambillah zakat dari sebagian harta mereka, dengan zakat itu kamu membersihkan dan mensucikan mereka dan mendo'alah untuk mereka. Sesungguhnya do'a kamu itu (menjadi) ketenteraman jiwa bagi mereka. Dan Allah Maha Mendengar lagi Maha Mengetahui."

Pada awal Surat At-Taubah ayat 103 ada kata "خحُن (khudz), dalam kaidah bahasa arab "حُذَ" termasuk fi'il amr yang berarti kata kerja perintah. Allah SWT memerintahkan Rasulullah SAW untuk mengambil sebagian (zakat) dari harta muzakki untuk membersihkan dan mensucikan muzakki . Dalam konteks saat ini, yang bertugas untuk mengambil zakat dari muzakki adalah amil zakat (lembaga zakat). Aksesibilitas lembaga zakat merupakan faktor yang berperan penting untuk mengambil (mengumpulkan) zakat dari muzakki.

Layanan jemput zakat dan kantor layanan zakat yang digunakan oleh lembaga zakat untuk mengambil (mengumpulkan) dana zakat sesuai dengan Surat At Taubah (9) ayat 103, وَمَلِ dimana setelah lembaga zakat mengambil (mengumpulkan) zakat dari muzakki, petugas lembaga zakat mendo'akan keberkahan dan memohonkan ampunan untuk muzakki.

Lembaga zakat yang kredibel dibutuhkan tidak hanya untuk menerima dana zakat, namun juga untuk mendistribusikan dan mendayagunakan dana zakat. Muzakki yang ingin membayarkan zakat harus memilih lembaga zakat yang kredibel. Sesuai dengan firman Allah SWT di Surat AlQashsh (28) ayat 26.

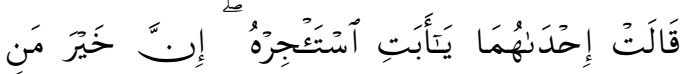

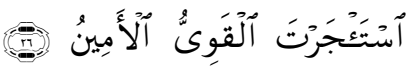

Artinya : "salah seorang dari kedua wanita itu berkata: "Ya bapakku ambillah ia sebagai orang yang bekerja (pada kita), karena Sesungguhnya orang yang paling baik yang kamu ambil untuk bekerja (pada kita) ialah orang yang kuat lagi dapat dipercaya"

Pada konteks lembaga zakat, "orang yang kuat" dapat dipahami sebagai lembaga zakat yang mampu untuk melaksanakan tugas mengumpulkan, mendistribusikan dan mendayagunakan dana zakat dengan baik. Selain itu, lembaga zakat harus "dapat dipercaya" dimana lembaga zakat bersifat amanah dalam mengelola dana zakat yang dibayarkan oleh muzakki. 
Lembaga zakat yang dipercaya oleh muzakki harus bekerja secara amanah dalam menjalankan fungsi dan tugasnya sebagai lembaga zakat. Sesuai dengan firman Allah SWT pada Surat Al-Anfal ayat 27.

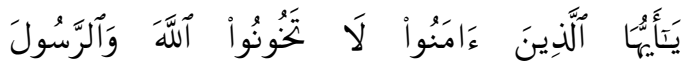

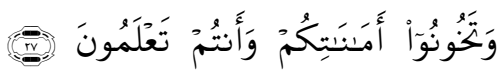

Artinya :"Hai orang-orang yang beriman, janganlah kamu mengkhianati Allah dan Rasul (Muhammad) dan (juga) janganlah kamu mengkhianati amanat-amanat yang dipercayakan kepadamu, sedang kamu mengetahui."

Penerimaan dana zakat BAZNAS Jawa Timur, Baitul Maal Hidayatullah, Yayasan Dana Sosial Al-Falah, Nurul Hayat, Rumah Zakat cabang Surabaya, dan Yatim Mandiri terbesar berasal dari layanan jemput zakat.

Penerimaan dana zakat Al-Azhar Peduli Ummat cabang Jawa Timur dan LAZ Masjid Al-Akbar Surabaya terbesar berasal dari muzakki yang langsung membayarkan di kantor lembaga zakat.

Pada seluruh lembaga zakat Payroll System masih belum banyak digunakan untuk melakukan penghimpunan dana zakat.

Laporan Kevangan Baitul Maal Hidayatullah, Yayasan Dana Sosial AlFalah, Nurul Hayat, Rumah Zakat, Al-Azhar Peduli Ummat, Yatim Mandiri, dan Pos Keadilan Peduli Ummat telah di audit eksternal oleh Kantor Akuntan Publik.

Penerimaan dana zakat seluruh lembaga zakat mengalami peningkatan berkali lipat di bulan Ramadhan. Peningkatan penerimaan dana zakat antara dua kali lipat hingga sepuluh kali lipat.

BAZNAS Jawa Timur, Baitul Maal Hidayatullah, Yayasan Dana Sosial AlFalah, Nurul Hayat, Rumah Zakat cabang Surabaya, Al-Azhar Peduli Ummat cabang Jawa Timur, Pos Keadilan Peduli Umat, dan LAZ Masjid Al-Akbar Surabaya tidak menggunakan sponsorship untuk melakukan penghimpunan dana zakat.

Pada seluruh lembaga zakat yang diteliti, masih sangat jarang dan bahkan tidak ada muzakki yang menanyakan program zakat memotong nilai penghasilan bruto pada perhitungan pajak penghasilan.

\section{SIMPULAN}

Simpulan yang dapat diambil dari pembahasan hasil penelitian ini adalah terdapat beberapa faktor yang berkontribusi terhadap jumlah penerimaan dana zakat pada lembaga zakat di Kota Surabaya, faktor tersebut yaitu:

Faktor teknologi pengumpulan dana zakat, Lembaga zakat memiliki teknologi yang cukup untuk melakukan pengumpulan dana zakat dengan adanya payroll system dan menyediakan rekening dari berbagai bank, namun kebanyakan muzakki belum memanfaatkan teknologi yang disediakan oleh lembaga zakat untuk membayarkan dana zakat. 
Faktor aksesibilitas berperan penting dalam penghimpunan dana zakat, dimana delapan dari sembilan lembaga zakat yang diteliti dalam penelitian ini, proporsi penerimaan dana zakat yang terbesar berasal dari aksesibilitas yang diberikan lembaga zakat kepada muzakki.

Faktor Kredibilitas. Lembaga zakat telah berupaya mempertahankan kredibilitas dengan melakukan audit eksternal terhadap laporan keuangannya.

Faktor Program. Program penghimpunan yang berperan penting adalah program penghimpunan ketika Bulan Ramadhan, dimana seluruh lembaga zakat mengalami kenaikan penerimaan dana zakat pada Bulan Ramadhan.

Saran yang direkomendasikan setelah melakukan penelitian faktor yang berkontribusi terhadap jumlah penerimaan dana zakat pada lembaga zakat di kota Surabaya adalah sebagai berikut :

1. Lembaga zakat hendaknya lebih giat mengedukasi muzakki mengenai ketentuan berzakat dan cara membayarkan zakat menggunakan teknologi yang tersedia. Edukasi ketentuan berzakat dan cara pembayaran zakat kepada muzakki dapat membuat muzakki dengan lebih mudah membayarkan zakat, dan juga penghimpunan dana zakat oleh lembaga zakat akan lebih efisien.

2. Lembaga zakat dapat bekerja sama dengan pihak perbankan untuk penghimpunan dana zakat yang lebih efisien. Cara yang dapat ditempuh adalah dengan mengadakan sosialisasi dan edukasi yang disertai penawaran kepada muzakki untuk memberikan standing instruction kepada bank untuk mendebet saldo rekening sesuai nominal zakat yang harus dibayarkan muzakki.

3. Lembaga Zakat seharusnya mencantumkan laporan keuangan secara rutin dan runtut waktu baik bulanan maupun tahunan pada website masing-masing lembaga zakat.

4. Bagi penelitian selanjutnya, disarankan melakukan penelitian dengan faktor yang lebih beragam. Ada banyak faktor yang belum diteliti dalam penelitian ini, seperti sinergi antara lembaga zakat dalam melakukan penghimpunan dana zakat, dan lain sebagainya.

\section{DAFTAR PUSTAKA}

Al-Qur'an dan Terjemahannya Departemen Agama Rl. 2006. Bandung: PT. Syamil Cipta Media.

Chaudhry, M. S. 2012. Sistem Ekonomi Islam Prinsip Dasar. Jakarta: Kencana Prenada Media Group.

Ghony, M. D., \& Almanshur, F. 2012. Metodologi penelitian kualitatif. Jogjakarta: Ar-Ruzz Media.

Hadits Riwayat Muslim.

Hafidhuddin, D. 2003. Islam aplikatif. Jakarta: Gema Insani. 
Hamidiyah, Emmy. 2004. Analisa FaktorFaktor yang Mempengaruhi Pengumpulan Zakat, Infak, Sedekah, Wakaf \& Kurban Pada Lembaga Pengelola Zakat (Studi Kasus: Dompet Dhuafa). Tesis tidak diterbitkan. Jakarta: Universitas Indonesia.

Huda, N. 2015. Zakat Perspektif Mikro Makro. Jakarta: Prenadamedia Group.

IMZ. 2012. Indonesia Zakat Development Report. Jakarta: IMZ.

Qardhawi, Y. 1999. Hukum Zakat. Jakarta: Pustaka Litera Antar Nusa.

Republik Indonesia. 2011. Undang-Undang No.23 Tahun 2011 tentang Pengelolaan Zakat. Lembaran Negara RI Tahun 2011. No. 115. Sekretariat Negara, Jakarta Widiastuti, T. 2014. Pengaruh Kepatuhan Berzakat Terhadap Kinerja Baz Dan Non-Baz Serta Kesejahteraan Mustahiq Di Jawa Timur Surabaya: Universitas Airlangga

Zadjuli, S. I. 1999. Prinsip - Prinsip Ekonomi Islam. Surabaya: Fakultas Ekonomi Universitas Airlangga.

www.businessdictionary.com, diakses pada 3 Nopember 2015 www.kbbi.web.id, diakses pada 3 Nopember 2015 